\title{
IHY: Meteor astronomy and the New Independent States (NIS) of the Former Soviet Union
}

\author{
Svetlana V. Kolomiyets ${ }^{1}$ and Vladimir V. Sidorov ${ }^{2}$ \\ ${ }^{1}$ Kharkiv National University of Radioelectronics, 14 Lenin Ave, Kharkiv, 61166, Ukraine \\ email: s.kolomiyets@gmail.com and kometa@kture.kharkov.ua \\ ${ }^{2}$ Kazan University, 18 Kremlyovskaya str., Kazan, Tatarstan, 420008, Russia \\ email: vladimir.sidorov@ksu.ru
}

\begin{abstract}
The purpose: to emphasize, that there are some specific features of the development of science in the New Independent States (NIS) of the Former Soviet Union. These features demand enhanced attention of the organizers of the IHY. It is necessary to create effective mechanisms for the stimulation of the connection to world science of the dormant part of fundamental scientific knowledge of these countries, which has been saved up for fifty of years. Probably, the IHY is the last opportunity of rescuing the dormant part of this knowledge from full oblivion.

The method adopted is to discuss and analyse the general tendencies in science in the NIS by reference to individual cases, in particular for meteor astronomy.

Results: The features and history of the development of meteor astronomy during the existence of the Soviet Union and the subsequent period give a key to understanding of the problem. Meteor astronomy can be assumed to be a young science. It is an example of a cross-disciplinary science. It is an example of a science having a sharp rise, due to the project of the IGY and to subsequent geophysical projects. Meteor astronomy is a science directly connected with the launching of the first space satellite of the Earth and the evaluation of problems of meteoroid danger to space missions.

Commission 22 (Division III) of the IAU coordinated the development of meteor astronomy during the IGY. The known Soviet researcher of meteors V. Fedynskiy headed this Commission during four years since 1958. In the USSR numerous meteor centres were created and activated. The general management was concentrated in Moscow. Despite the close interaction under global projects of the Soviet Union with other countries, there still existed a language barrier. The language barrier, together with other reasons, has led to the creation in the USSR of a powerful meteor science, but only in the Russian language.

After the disintegration of the Soviet Union, the meteor centres have remained, but without ordinary central management. The scientific results have remained but as an isolated, inaccessible science published in English.

Conclusion: Reunification of the scientific achievements of the last few years in the NIS with international science should become the task of the IHY. Revival of the activity of the some of the centres will be useful.
\end{abstract}

Keywords. History and philosophy of astronomy, atmospheric effects, meteors, meteoroids, meteor radar techniques, space vehicles, interplanetary medium, solar-terrestrial relations

\section{Introduction}

A new programme of global coordinated researches on the interaction of the Sun's radiation with the Earth, planets and interplanetary space of the solar system will start in 2007. It is the fourth programme under the account from a series of the International Geophysical Years. One of the aspects of this programme is the preservation of an historical heritage of programmes of the earlier geophysical years, and, first of all, the International 


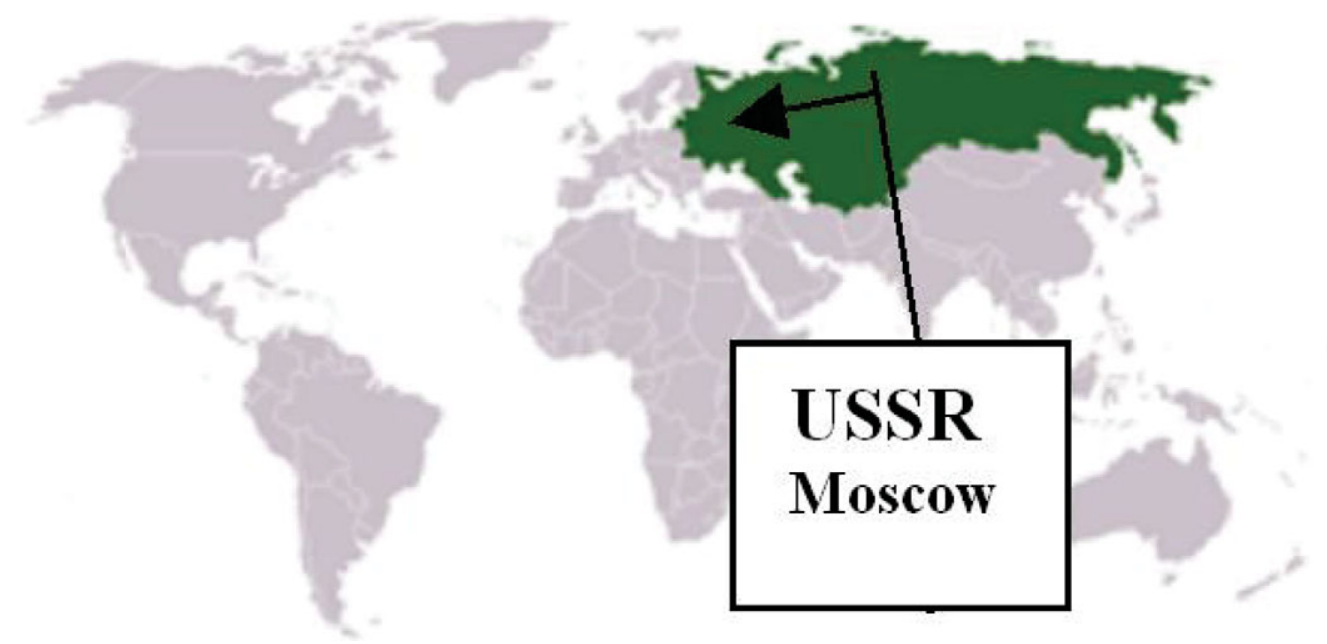

Figure 1. The territory of the USSR before the collapse, showing Moscow, the capital of the USSR, 1922-1991

Geophysical Year IGY1957. As an historical heritage of the third geophysical year from all of the received knowledge during IGY 1957, it is necessary to preserve our knowledge of meteor astronomy and meteor geophysics. It concerns knowledge of meteors which have been saved up in Russian in the Soviet Union since the time of carrying out of the third year. This knowledge in the countries of the former Soviet Union is now under the threat of full oblivion.

\section{Post-Soviet space (NIS)}

The Soviet Union was dissolved in 1991, and the successor states are a collection of 15 countries commonly dubbed "the Former Soviet Union". For several years after 1991 these states were commonly referred to as the "New Independent States" (NIS). As the abruptness of the fall of the Soviet Union faded, geographic-historical terms began to be used more often, such as "Eurasia" or the "Former Soviet Union". Within Russia, the former non-Russian republics have commonly been referred to collectively as the "near abroad", and the 15 successor countries together as "Post-Soviet space". Before the collapse, the Soviet Union had the most area of any territory $\left(22402200 \mathrm{~km}^{2}\right)$ and the third highest population (299047571) on a global scale.

Today in the countries of the post-Soviet space, Russian as the working language of the scientific environment still continues to remain the most widespread. In these postSoviet countries the Russian language continues for historical reasons to be the most widespread language for official communications and general understanding. For today's Russian-speaking sphere constitutes 4 per cent of all population of the Earth and 5 per cent of the land area from all the territories of the world (Table 1).

The purpose of this paper is to emphasize, that there are some specific features of the development of science in the New Independent States (NIS) of the Former Soviet Union. These features demand enhanced attention by the organizers of the IHY in general and the United Nations in particular. It is necessary to create effective mechanisms for the stimulation of the connection to world science of the dormant part of fundamental scientific knowledge of these countries (in Russian) which has been saved up for some 
Table 1. Percentages of the world population and of the Earth's land surface area for some countries and for the NIS

Rank from $234 \quad$ Country Per cent population of world Per cent area of world

\begin{tabular}{rrrl}
\hline 1 & China & 20.10 & 1.88 \\
2 & India & 16.86 & 0,64 \\
3 & USA & 4.59 & 1.89 \\
4 & NIS & 4.40 & 5.27 \\
5 & Indonesia & 3.79 & 0.38 \\
6 & Brazil & 2.89 & 1.67 \\
7 & Bangladesh & 2.54 & 0.03 \\
8 & Pakistan & 2.26 & 0.16 \\
9 & NIS minus Russia & 2.21 & 1.92 \\
10 & Russia & 2.19 & 3.35 \\
28 & Ukraine & 0.72 & 0.12 \\
\hline
\end{tabular}

fifty years, since the IGY. Probably, the International Heliophysical Year 2007 is the last opportunity of rescuing the dormant part of this knowledge from full oblivion.

The method adopted is to discuss and analyse the general tendencies in science in the NIS by reference to individual cases, in particular for meteor astronomy. Features and the problem of the development of meteor astronomy during the existence of the Soviet Union, and the subsequent period, give a key to understanding of the problem.

\section{Some history of the USSR (1953-1969): the rise to power}

Joseph Stalin died on March 5, 1953. In the absence of an acceptable successor, the highest Communist Party officials opted to rule the Soviet Union jointly, although a struggle for power took place behind the facade of collective leadership. Nikita Khrushchev, who won the power struggle by the mid-1950s, denounced Stalin's repression in 1956, and he eased repressive controls over the party and society. During this period, the Soviet Union continued to realize scientific and technological pioneering exploits, including to launch the first artificial satellite Sputnik 1, to launch the living being, Laika, and later, the first human being, Yuri Gagarin, into Earth orbit.

This period closely connects with the preparation and carrying out of the International Geophysical Year 1957. In the Soviet Union for a long time, beginning with the start of the Cold War in 1947, there was an initiative to catch up and overtake leading western capitalist countries, including in the domain of scientific achievements. Therefore, the preparation and carrying out of IGY 1957 in the USSR were high-quality and well organized. These activities were supervised at the highest level and have been supported by the state and regional financing. Carrying out of meteor researches in the frame of the IGY and during the subsequent geophysical programmes (the International Year of Geophysical Cooperation, the International Year of the Quiet Sun), was extraordinary successful. It has led to significant development of meteor astronomy, to the monumental boom in accumulation of knowledge on meteor astronomy, especially so in the Soviet Union and in the Russian language.

An especially important place in meteor astronomy was borrowed with a new young branch of a meteor science, connected with the radar-location of meteors. A separate interest has been that section of meteor astronomy connected with the evaluation of the meteoroid danger to space flights and the creation of a model of the distribution of meteor substances. 


$\begin{array}{ll}\text { SovietRepublics } & \text { Independent Countrie } \\ \text { Armenian SSR } & \text { 1-Armenia } \\ \text { Azerbaijan SSR } & \text { 2-Azerbaijan } \\ \text { Byelorussian SSR } & \text { 3-Belarus } \\ \text { Estonian SSR } & \text { 4-Estonia } \\ \text { Georgian SSR } & \text { 5-Georgia } \\ \text { Kazakh SSR } & \text { 6-Kazakhstan } \\ \text { Kyrgyz SSR } & \text { 7-Kyrgyzstan } \\ \text { Latvian SSR } & \text { 8-Latvia } \\ \text { Lithuanian SSR } & \text { 9-Lithuania } \\ \text { Moldavian SSR } & \text { 10-Moldova } \\ \text { Russian SFSR } & \text { 11-Russia } \\ \text { Tajik SSR } & \text { 12- Tajikistan } \\ \text { Turkmen SSR } & \text { 13-Turkmenistan } \\ \text { Ukrainian SSR } & \text { 14-Ukraine } \\ \text { Uzbek SSR } & \text { 15-Uzbekistan }\end{array}$

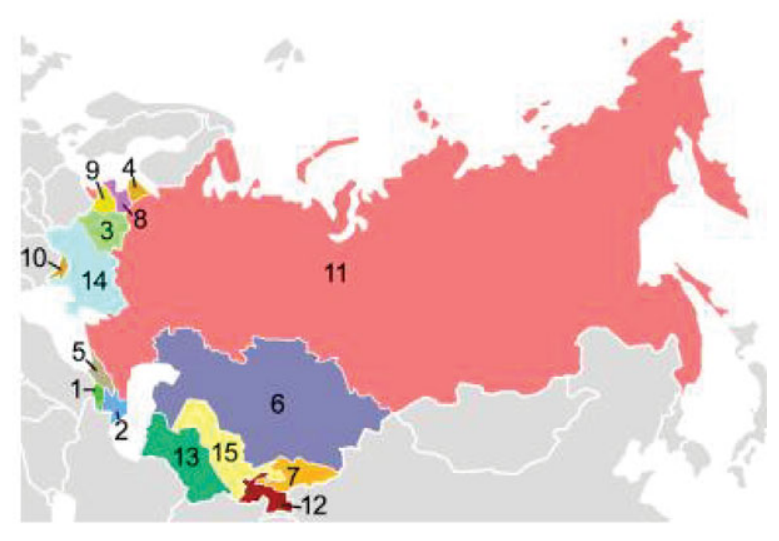

Figure 2. List of the 15 New Independent States of the Former Soviet Union and 15 Soviet republics before the collapse

This aspect of meteor research is closely connected with the successful launch of the first artificial satellites of the Earth, and the transformation of the USSR into the firstever space power. However, meteor science, working in Russian, has appeared to be in significant isolation from the international scientific communities. There was a linguistic barrier and also a political barrier. Besides, meteor science became a strategic science and for many interesting developments in meteor astronomy there was a ban on publication in the open press. This was especially rigid and an exacerbation during the cold war period.

\section{Importance of section 5, "Ionosphere", in the programme of the International Geophysical Year}

Each of the programmes of geophysical years had features connected to a history of development of human society in general and to those problems of geophysics in particular, which in turn were generated by the prevailing historical period. IGY1957 has been led in 25 years after the second year and its triumphal carrying out was promoted by a lot of favorable circumstances.

First of all, on a global scale, it was a time of economic rise and relative social wellbeing. The development of science and technology has achieved such a high level, such that it was possible to launch the first artificial satellite of the Earth. This has opened for mankind a new era in the conquest of space.

The IGY activities of the year 1957 were on a grand scale in every respect. The transition from studying separate aspects of geophysics to its universal study was made.

From all the broadest set of subjects of research, on which the third international geophysical year has enriched mankind with new knowledge, it is necessary to allocate, as a key, the section 5 programmes concerning the "Ionosphere". To investigate this section, it is necessary to make use of the expanded variant, which is used in all materials under the programme of each year in the Soviet Union, under titles such as "Ionosphere and meteors".

The ionosphere is the part of the atmosphere (near $60-1000 \mathrm{~km}$ ) that is ionized by solar radiation. The meteor zone lies in the frame of the ionosphere near between 70-140 km. Edward V. Appleton was awarded in 1947 a Nobel Prize for his confirmation of the existence of the ionosphere in 1927. In 1950 L. Berker (one of the pioneers for studying 
of the ionosphere, the well-known American scientist) initiated to lead the third polar year in 25 years after IPY 2.

A proposal for IGY 1957 was brought before the Mixed Commission on the Ionosphere, which duly endorsed it. The Mixed Commission on the Ionosphere for IGY 1957 was formed by the International Council of Scientific Unions (ICSU), under the sponsorship of the International Union for Radioscience (URSI), with the co-operation of the International Astronomical Union (IAU) and the International Union for Geodesy and Geophysics (IUGG).

A bright example of the scale of the third year in the domain of the ionosphere is the fact, that within the second polar year, there worked six ionospheric research stations, and during the third year, work at not less than 300 ionosphere stations was planned. Such interest in the ionosphere is dictated not only by scientific geophysical problems. During the second polar year, ionosondes were necessary only for meteorology. But during the third geophysical year, new important and practical interests in the ionosphere were developed. These were connected with the wide introduction of a new radio engineering method of researches, and with modern (for that time) and most reliable means of communications by radio communications that appeared.

In 1920 the Department of Scientific and Industrial Research formed the Radio Research Board, in order to 'Direct any research of a fundamental nature that may be required, and any investigation having a civilian as well as a military interest'. The term RADAR was coined in 1941 as an acronym for Radio Detection and Ranging. This acronym, of American origin, replaced the previously used British abbreviation RDF (Radio Direction Finding) in 1942. The term has since entered the English language as a standard word 'radar', losing the capitalization in the process. The famous Sir Bernard Lovell, the British radio astronomer, and director (until 1981) and founder of the Jodrell Bank Observatory (at first the Jodrell Bank Experimental Station) did radar research and radar meteor research.

\section{Phenomenon of meteor astronomy in Russia and the International Geophysical Year 1957}

Many aspects of meteors have appeared extremely important for IGY 1957, both in the USSR, and in other countries, in connection with the approach of the space age and the revolutionary introduction in scientific researches of radar-tracking methods. Meteors became one of the central objects of research during IGY 1957. Meteors were a highlight in the IGY section "the Ionosphere". Their value for IGY 1957 was unique, as they were not only a subject of study, but were one of the main indirect means of studying the top layers of the atmosphere of the Earth, the circulation of the atmosphere and its parameters within the limits of the ionosphere.

Besides, meteors had one more important independent function as a means of radio communication. Meteoric communication was an alternative at times of infringements or difficulties in the use of usual radio communication, or for confidential purposes. Radio and meteors have enriched each other. With the application in meteor researches of radio engineering means and radar-tracking methods (the most advanced during IGY 1957) it began to be possible to provide meteor astronomy and meteor geophysics with an extensive observational material, not dependent on the season or time of day. It was also possible partially to automate the process of the accumulation of data, and to register weaker meteors.

The stunning file of knowledge on meteors within the limits of IGY 1957 on the volume and the importance has been received in Soviet Union. 


\subsection{Special place of the Kharkiv and Kazan radar meteor centers and the development of radar methods of research on meteors in the Soviet Union}

It is necessary to note the important role of the Kharkiv and Kazan radar meteoric centres and the development of radar-tracking methods of research of meteors in Soviet Union, since preparation and participation in the project of the International Geophysical Year.

The Kazan researchers under K.V. Kostylev's manual have played a leading role in 50th years of the twentieth century in distribution of meteoric radar knowledge to the USSR and training of the future participants of the meteor program of Soviet Union to known radar methods of research of meteors in an atmosphere of the Earth and their practical realization. Subsequently, during the period with 1960 on 1986 they have created some new radar systems, which allowed to specify electrodynamic of meteoric scattering of radio wave and to execute long-term monitoring of inflow of meteoric substance on the basis of use of statistical methods of analysis of the received data?.

The Kharkiv researchers under the direction of B.L. Kashcheyev have spent the best cycle of radar observations during performance of program IGY 1957-1959, have improved the equipment for research of meteors and subsequently in 1968-1972 have created for the first time in the USSR the multipurpose automated radar system MARS for research of meteors in an atmosphere of the Earth with registration of orbits of radiometeors up to the twelfth star magnitude (one of the best and high-sensitivity in the world by the beginning of 70th years of the twentieth century). Besides for last 50 years in the Kharkiv meteor center the cycle of works on studying physics of the meteoric phenomena in an atmosphere of the Earth and on research of orbital properties of an interplanetary meteoric complex is executed in view of factors of selectivity on the basis of own long-term lines radar observations of meteors.

\section{Some history of the USSR (1970-1991) and of the NIS: the recession}

However, since the 1970s, the growth rate of meteor knowledge had slowed substantially. Extensive economic development, based on vast inputs of materials and labour, was no longer possible; yet the productivity of Soviet assets remained low compared with other major industrialized countries.

Besides, the period 1979-1985 is sometimes referred to as the "Second Cold War". It was marked with a change in the Western policy of detente and more confrontation against the Soviets. The meteor science in Russian basically remained an unknown item for meteor international science in English. Prior to its collapse, the Soviet Union had the largest centrally directed economy in the world. The government established its economic priorities through central planning. With disintegration of the Soviet Union and formation of the 15 new independent states, the situation with meteor astronomy became catastrophic.

Meteor astronomy in the 14 newly formed countries could probably have been developed. However, the problems were that the scientists found themselves without the usual central Moscow management system, which included the Committee on comets and meteors of Astronomical Advice of the USSR, and the Section of Interdepartmental Geophysical Committee at the Academy of Sciences of the USSR. In addition, a stable military was lacking and the former Soviet space program was also an impetus for meteor astronomy. In particular there was no motivation to reactivate the Soviet scientific structures that had previously demanded that meteor astronomy be pursued. 


\section{The developing world and the NIS}

The terms 'First World', 'Second World', and 'Third World' can be used to divide the nations of Earth into three broad categories. At first, the term Third World had a political status during the Cold War. Today the term Third World is frequently used to denote nations with a low UN Human Development Index (HDI), independently of their political status.

The Human Development Index (HDI) is a comparative measure of poverty, literacy, education, science, life expectancy, childbirth, and other factors for countries worldwide. It is used to distinguish whether the country is a developed, developing, or an underdeveloped country, and also to measure the impact of economic policies on quality of life. An HDI below 0.5 is considered to represent low development and 30 of the 32 countries in that category are located in Africa, with the exceptions of Haiti and Yemen.

There are three country in Europe from the NIS group with a low HDI: Georgia (100), Azerbaijan (101) and Moldova (115). An HDI 0.8 or more is considered to represent high development. This includes countries of northern and western Europe, North America, the Southern Cone, the East Asian Tigers, Japan, Australia, New Zealand, Israel, Kuwait and the UAE.

There are two human poverty indexes for developing countries (HPI-1) and for selected OECD countries (HPI-2). (OECD is the Organization for Economic Co-operation and Development.) The last report of the United Nations (UN), 2003, only has a ranking for 17 of the 21 OECD countries with the highest Human Development Index. They are the United States (HP2-15.8), Ireland, United Kingdom, Australia, Belgium, Canada, Italy, Japan, Spain, France, Luxembourg, Germany, Denmark, Netherlands, Finland, Norway, Sweden (HP2-6.5). The following four from 21 OECD countries that are not on this list are Iceland, Switzerland, Austria, and New Zealand. There is no objective definition of Third World or "Third World country" but the use of the term remains common. The term Third World is also disliked, as it may imply the false notion that those countries are not a part of the global economic system. In general, Third World countries are not as industrialized or technologically advanced as OECD countries, and therefore in academia, the more politically correct term to use is "developing nation" or "developing world".

Countries that have more advanced economies than developing nations but haven't yet gained the level of those in the First World are grouped under the term Newly Industrialized Countries or NICs (e.g. China, India, Mexico or South Africa). In Table 2 we can see estimates of population and its dynamic for the most populous ten countries and for the NIS. Low and even negative values of parameters of an increase in population for the countries of the post-Soviet space reflect the fact, that these developing countries have serious problems, such as economic, and others. These problems are characteristic of the transition periods of states, which change their political system. However these usual transitional problems and the destroying of the old settled connections in the countries of the post-Soviet space are adverse for development in these countries of all sciences in general, and astronomy, in particular.

\section{NIS problems and the UN outreach programme}

The UN report for 2005 shows that, in general, the HDI for countries around the world is improving, with two major exceptions: Post-Soviet states (NIS), and Sub-Saharan Africa, both of which show a steady decline. Worsening education, economies, and mortality rates have contributed to HDI declines amongst countries in the first group, while 
Table 2. Current world population (selected and ranked from 232)

rank country area (sq.km) population estimate at 2006-07-01 yearly growth (\%)

\begin{tabular}{rrccc}
\hline & World & $510,072,000$ & $6,525,170,300$ & 1.14 \\
1. & China & $9,596,960$ & $1,313,973,700$ & 0.59 \\
2. & India & $3,287,590$ & $1,095,352,000$ & 1.38 \\
3. & USA & $9,631,418$ & $298,444,200$ & 0.91 \\
4. & Indonesia & $1,919,440$ & $245,452,700$ & 1.41 \\
5. & Brazil & $8,511,965$ & $188,078,200$ & 1.04 \\
6. & Pakistan & 803,940 & $165,803,600$ & 2.09 \\
7. & Bangladesh & 144,000 & $147,365,400$ & 2.09 \\
8. & Russia & $17,075,200$ & $142,893,500$ & -0.37 \\
9. & Nigeria & 923,768 & $131,859,700$ & 2.38 \\
10. & Japan & 377,835 & $127,463,600$ & 0.02 \\
26. & Ukraine & 603,700 & $46,710,800$ & -0.60 \\
42. & Uzbekistan & 447,400 & $27,307,100$ & 1.70 \\
77. & Belarus & 207,600 & $10,293,000$ & -0.06 \\
92. & Azerbaijan & 86,600 & $7,961,600$ & 0.66 \\
96. & Tajikistan & 143,100 & $7,320,800$ & 2.19 \\
111. & Kyrgyzstan & 198,500 & $5,213,900$ & 1.32 \\
113. & Turkmenistan & 488,100 & $5,042,900$ & 1.83 \\
115. & Georgia & 69,700 & $4,661,500$ & -0.34 \\
120. & Moldova & 33,843 & $4,466,700$ & 0.28 \\
130. & Lithuania & 65,200 & $3,585,900$ & -0.30 \\
136. & Armenia & 29,800 & $2,976,400$ & -0.19 \\
142. & Latvia & 64,589 & $2,274,700$ & -0.67 \\
151. & Estonia & 45,226 & $1,324,300$ & -0.64 \\
\hline
\end{tabular}

Human Immunodeficiency Virus/Acquired Immune Deficiency Syndrome (HIV/AIDS) and concomitant mortality is the principal cause of decline in the second group.

The United Nations Development Programme (UNDP), the United Nations' global development network, is the largest multilateral source of development assistance in the world. The UNDP is on the ground in 166 countries, working on global and national development challenges. UNDP provides expert advice, training, and grant support to developing countries, with increasing emphasis on assistance to the least developed countries.

The Human Poverty Index is an indication of the standard of living in a country, and was developed by the UN. The UN considers this a better indicator than the Human Development Index, which in turn is considered a better indicator than the Gross Domestic Product. For an understanding of all the problems of the NIS, it is necessary to study different indexes (Table 3).

The UNBSSI IHY programme is deploying arrays of small, inexpensive instruments around the world, especially in developing nations, to provide global measurements of geospace and heliospheric phenomena. It also hosts annual workshops dedicated to the IHY programme through 2009. 
Table 3. The Gross Domestic Product for NIS countries. GDP dollar estimates here are derived from purchasing power parity (PPP) calculations. The data are provided by the International Monetary Fund (IMF). For comparison, max. and min. GDP figures are $\$ 12,277 \mathrm{~B}$ (USA) and $\$ 221 \mathrm{~m}$ (Kiribati). Max. and min. GDP/capita are $\$ 69,800$ (Luxembourg) and $\$ 596$ (Malawi).

Country of NIS Country code/ GDP (PPP) \$m GDP per capita, \$ Region (alphabetical order) capital

\begin{tabular}{lrccl}
\hline 1. Armenia & AM/Yerevan & $14,167(127 \mathrm{th})$ & $4,270(115 \mathrm{th})$ & Western Asia \\
2. Azerbaijan & AZ/ Baku & $38,708(88 \mathrm{th})$ & $4,601(107 \mathrm{th})$ & Western Asia \\
3. Belarus & BY/Minsk & $75,217(64 \mathrm{th})$ & $7,711(79 \mathrm{th})$ & Eastern Europe \\
4. Estonia & EE/Tallin & $22,118(106 \mathrm{th})$ & $16,414(43 \mathrm{th})$ & Northern Europe \\
5. Georgia & GE/Tbilisi & $15,498(122 \mathrm{th})$ & $3,586(122 \mathrm{nd})$ & Western Asia \\
6. Kazakhstan & SQ/Astana & $125,522(56 \mathrm{th})$ & $8,318(70 \mathrm{th})$ & South-central Asia \\
7. Kyrgyzstan & KG/Bishkek & $10,764(134 \mathrm{th})$ & $2,088(141 \mathrm{st})$ & South-central Asia \\
8. Latvia & LV/Riga & $29,214(95 \mathrm{th})$ & $12,666(53 \mathrm{rd})$ & Northern Europe \\
9. Lithuania & LT/Vilnius & $48,493(75 \mathrm{th})$ & $14,158(49 \mathrm{th})$ & Northern Europe \\
10. Moldova & MD/Chisinau & $8,563(141 \mathrm{st})$ & $2,527(131 \mathrm{st})$ & Eastern Europe \\
11. Russia & RU/Moscow & $1,575,561(10 \mathrm{th})$ & $11,041(62 \mathrm{nd})$ & Eastern Europe \\
12. Tajikistan & TJ/Dushanbe & $8,802(139 \mathrm{th})$ & $1,388(159 \mathrm{th})$ & South-central Asia \\
13. Turkmenistan & TM/Ashgabat & $40,685(88 \mathrm{th})$ & $8,098(73 \mathrm{rd})$ & South-central Asia \\
14. Ukraine & UA/Kiev & $338,486(28 \mathrm{th})$ & $7,213(86 \mathrm{th})$ & Eastern Europe \\
15. Uzbekistan & UZ/Tashkent & $50,395(74 \mathrm{th})$ & $1,920(145 \mathrm{th})$ & South-central Asia \\
& & & &
\end{tabular}

\section{Appendix I: Addresses of organizations coordinating meteor research in the USSR during the IGY, 1957}

1. Moscow, B. Gruzinskaja 10, Astronomical Council AS of the USSR, Commission on Comets and Meteors

2. Odessa, Park named Shevchenko, Astron. Observ. of Odessa Univ. (parent organization of the meteor service of the USSR during the IGY period)

3. On organizational questions: Moscow, Kaluga Highway 71, Interdepartmental Committee of IGY at Presidium AS of the USSR, working group for studying meteors

4. For sending materials: Moscow area, post Vatutenki, Scientific Research Institute of Terrestrial Magnetism, Ionosphere and the Distribution of Radiowaves (now IZMIRAN) 
Appendix II: Participants of IGY program on meteor research in the USSR

\title{
Participants of program IGY 1957 on meteor research in the USSR
}

\author{
$\mathrm{R}$ - radar, Ph - photographic, V - visual
}

\begin{tabular}{|c|c|c|c|c|c|c|}
\hline $\mathrm{N}$ & City & $\varphi$ & $\lambda$ & $\begin{array}{l}H \\
\mathbf{m}\end{array}$ & Scientific institutes / Country / Chairs & $\begin{array}{l}\text { Program, } \\
\text { Nigy }\end{array}$ \\
\hline 1 & Ashkhabad & $\begin{array}{ll}37^{\circ} \\
56^{\circ}\end{array}$ & $58^{\circ}$ & 200 & $\begin{array}{l}\text { Astrophysical Laboratory of the Institute of Physics } \\
\text { and Geophysics AS Turkmen SSR } \\
\text { I.A. Astapowich, Ya.F. Sadykov. }\end{array}$ & $\begin{array}{l}\text { R, Ph, V } \\
\text { N696 } \\
\text { (C126) }\end{array}$ \\
\hline 2 & Kazan & $\begin{array}{l}55^{\circ} \\
47^{\prime}\end{array}$ & $\begin{array}{l}49^{\circ} \\
07^{\prime}\end{array}$ & 80 & $\begin{array}{l}\text { Astronomical observatory named Engelgardt of the } \\
\text { Kazan University Russian SFSR K.V. Kostylyov. }\end{array}$ & $\begin{array}{l}\mathbf{R} \\
\mathrm{N} 233\end{array}$ \\
\hline 3 & $\underline{\underline{\text { Kiev }}}$ & $\begin{array}{l}50^{\circ} \\
27^{\circ}\end{array}$ & $\begin{array}{l}30^{\circ} \\
30^{\prime}\end{array}$ & 185 & $\begin{array}{l}\text { Astronomical observatory of the Kiev University } \\
\text { Ukrainian SSR A.F.Bogorodskiy, }\end{array}$ & $\begin{array}{l}\text { R, Ph, } \\
\text { N320 }\end{array}$ \\
\hline 4 & Odessa & $\begin{array}{l}46^{\circ} \\
29^{\circ}\end{array}$ & $\begin{array}{l}30^{\circ} \\
46^{\prime}\end{array}$ & 50 & $\begin{array}{l}\text { Astronomical observatory of the Odessa University } \\
\text { Ukrainian SSR V.P.Tsesevich, E.N. Kramer }\end{array}$ & $\begin{array}{l}\text { R, Ph, V } \\
\text { N621 }\end{array}$ \\
\hline 5 & $\begin{array}{l}\text { Stalinabad } \\
\text { Dushanbe }\end{array}$ & $38^{\circ}$ & $\begin{array}{l}68^{\circ} \\
46^{\prime}\end{array}$ & 820 & $\begin{array}{l}\text { Institute of Astrophysics AS Tajik SSR } \\
\text { L.A. Katasev, P.B. Babadzhanov, A.M. Bakharev. }\end{array}$ & $\begin{array}{l}\text { R, Ph, V } \\
\text { N680 } \\
\text { (C115) }\end{array}$ \\
\hline 6 & Tonsk & $\begin{array}{l}56^{\circ} \\
29^{\prime}\end{array}$ & $\begin{array}{l}84^{\circ} \\
59^{\prime}\end{array}$ & 120 & $\begin{array}{l}\text { Tomsk Polytechnical Institute ( faculy of Radiophysics) } \\
\text { Russian SFSR Ye.F.Fialko. }\end{array}$ & $\begin{array}{l}\text { R } \\
\mathrm{N} 224\end{array}$ \\
\hline 7 & Kharkov & $\begin{array}{l}50^{\circ} \\
00^{\prime}\end{array}$ & $\begin{array}{l}36^{\circ} \\
14^{\prime}\end{array}$ & 140 & $\begin{array}{l}\text { Kharkov Polytechnical Institute (faculy of } \\
\text { Radioengineering) Ukrainian SSR B.L. Kashcheyev }\end{array}$ & $\begin{array}{l}\mathrm{R} \\
\mathrm{N} 358(\mathrm{~B} 141\end{array}$ \\
\hline
\end{tabular}

\section{Acknowledgements}

The authors acknowledge Wikipedia, the free internet encyclopedia, for very informative articles and pictures that were used in this contribution. S.V.K. is thankful to the IAU and to the Academy of Sciences of the Czech Republic for awarding her a grant to attend the XXVIth General Assembly and, personally, to John Hearnshaw (SPS5 chair), Oddbjorn Engvold (IAU General Secretary) and Jan Palous (GA NOC Chair) for their helpful assistance. S.V.K. also thanks the organizers of Special Session 5 of the XXVIth GA for acceptance of this contribution for publication, and especially to John Hearnshaw for his active help in the preparation of this paper. 